\title{
Publisher Correction: Direct dioxygen evolution in collisions of carbon dioxide with surfaces
}

Yunxi Yao ${ }^{1,2}$, Philip Shushkov ${ }^{1,2}$, Thomas F. Miller III (1D ${ }^{1}$ \& Konstantinos P. Giapis (1) ${ }^{1}$

Correction to: Nature Communications https://www.nature.com/articles/s41467-019-10342-6, published online 24 May 2019.

The original version of this Article contained errors in Fig. 1. The titles at the top of each panel a, b, $\mathrm{c}$ were incorrectly given as ' $\mathrm{CO}{ }_{2}{ }^{+} /$ $\mathrm{Au} \rightarrow \mathrm{CO}_{2}{ }^{+} \mathrm{A}^{\prime}$ ' ' $\mathrm{CO}_{2}{ }^{+} / \mathrm{Au} \rightarrow \mathrm{CO}_{2}{ }^{+} \mathrm{B}^{\prime}$ and ' $\mathrm{CO}_{2}{ }^{+} / \mathrm{Au} \rightarrow \mathrm{O}_{2}^{-} \mathrm{C}^{\prime}$ ' instead of the correct panel a, b, c ' $\mathrm{CO}_{2}{ }^{+} / \mathrm{Au} \rightarrow \mathrm{CO}_{2}{ }^{+}$', ' $\mathrm{CO}_{2}{ }^{+} / \mathrm{Au} \rightarrow$ $\mathrm{O}_{2}{ }^{+}$' and ' $\mathrm{CO}_{2}+/ \mathrm{Au} \rightarrow \mathrm{O}_{2}{ }^{-}$, , respectively. This has been corrected in the PDF and HTML versions of the Article.

Published online: 18 June 2019

\begin{abstract}
(c) Open Access This article is licensed under a Creative Commons Attribution 4.0 International License, which permits use, sharing, adaptation, distribution and reproduction in any medium or format, as long as you give appropriate credit to the original author(s) and the source, provide a link to the Creative Commons license, and indicate if changes were made. The images or other third party material in this article are included in the article's Creative Commons license, unless indicated otherwise in a credit line to the material. If material is not included in the article's Creative Commons license and your intended use is not permitted by statutory regulation or exceeds the permitted use, you will need to obtain permission directly from the copyright holder. To view a copy of this license, visit http://creativecommons.org/licenses/by/4.0/.
\end{abstract}

(C) The Author(s) 2019

\footnotetext{
${ }^{1}$ Division of Chemistry and Chemical Engineering, California Institute of Technology, Pasadena, CA 91125, USA. ${ }^{2}$ These authors contributed equally: Yunxi Yao, Philip Shushkov. Correspondence and requests for materials should be addressed to K.P.G. (email: giapis@cheme.caltech.edu)
} 